\title{
Android-Based Waste Education App: An Information Media on Zero-Waste Programs
}

\author{
Muhammad Zamroni Uska ${ }^{1}$, Rasyid Hardi Wirasasmita ${ }^{1}$, Baiq Desi Dwi Arianti ${ }^{1}$, Yosi Nur \\ Kholisho' ${ }^{1}$, Muhammad Djamaluddin ${ }^{2}$, Jamaludin ${ }^{1}$ \\ ${ }^{1}$ Department of Informatics Education, Universitas Hamzanwadi \\ ${ }^{2}$ Department of Informatics Engineering, Universitas Hamzanwadi \\ E-mail: zamroniuska@gmail.com
}

\begin{abstract}
Zero waste is one of the programs from the government of West Nusa Tenggara Province in Indonesia, where this program aims to provide education about waste to the public so that the waste can be processed or recycled so that it can be useful. Therefore, for the sake of creating a zero-waste culture in the community, it is necessary to have media that provide education to the public about this program. The purpose of this article is to discuss the process of developing an Android-based waste education application as a medium of information about zero waste. This study uses the ADDIE model to make this product with five steps, namely analysis, design, development, implementation and evaluation. The data collection technique used was a questionnaire with a Likert scale, and the subjects in this study were the 60 people in the Menceh village. The data analysis technique used is descriptive quantitative. Our findings show that this application (media) is declared very-feasible by material (content) experts with a score of $85 \%$ and media (design) experts (83\%), and user usability is in the very-high category $(83 \%)$. So, it can be concluded that this application is feasible to use properly, so that users can obtain information about how to manage waste through a zero-waste program.
\end{abstract}

Keywords: zero waste, information media, education, android

\section{INTRODUCTION}

In the current era, various problems related to wasting cannot be completely resolved. Waste in Indonesia is a very serious problem and also a social, economic and cultural problem. In social conditions, poor Waste Management will create an unfavorable environment for the community, and almost all cities in Indonesia's experience problems in processing waste. People still like to throw garbage carelessly. Although there have been many efforts made by the government to deal with waste.

Waste problems can be overcome by good processing [1], and by reducing, reusing, and recycling [2]-[4]. In addition, it is very necessary for large waste transportation services, sufficient or adequate number of personnel, timeliness/regularity of schedules and accuracy of waste objects, namely it will be easy to solve the problem of waste and environmental cleanliness properly.
The Law of the Republic of Indonesia Number 18 of 2008 concerning Waste Management states that population growth and consumption patterns affect to gain the volume, types, and characteristics of increasingly diverse waste. Based on data from the Central Statistics Agency (BPS) as revealed by [5] waste produced increases annually by 67.1 million tons when compared to the previous year (2018).

The low level of public awareness and concern for waste, and the inadequate availability of land for making closets, have an impact on environmental cleanliness. Therefore, alternative handling efforts must be carried out so that problems regarding waste can be resolved. A clean and healthy environment can be promoted by using and managing waste properly and correctly. According to Fagnani \& Guimarães, adequate waste management provides environmental and economic benefits [6].

Concern for the environment is fundamental in encouraging one's awareness of 
the environment around him. This awareness can take the form of taking action to protect the environment, love cleanliness, and be wiser in managing and utilizing everything in the environment. Humans as thinking creatures must be able to take advantage of everything in the environment, especially in managing waste properly. In addition, based on Governor Regulation number 44 of 2019 articles three numbers 3, one of the flagship programs launched by the West Nusa Tenggara provincial government in Indonesia is about Environmental Gemilang, one of which is about zero waste [7].

According to Widiarti, the zero waste principle is a waste processing concept based on recycling activities. The concept of dealing with waste systematically will reduce the amount to preserve and restore environmental resources, so that waste from community activities will be handled properly, such as making flowers from used plastic, compost from organic waste, bags from coffee sachets and so on [8].

Zero wastes also have an important role for environmental cleanliness and are carried out by Reduction, Reuse, and Recycling [9], [10]. Other opinions state that zero waste is a series of actions aimed at eliminating waste and challenging traditional Waste Management systems [11]-[14]

Based on the results of observations that have been made to the community in Menceh Village, a lifestyle that still litters tend to cause more and more garbage piles not only in the yard but also on the side of the road. The damage is getting worse. Based on the results of interviews with several community leaders, it was confirmed that there was a lack of government approach and socialization in the community regarding handling, processing and regulations that were closely related to waste. In addition, there are no socialization activities about the dangers and benefits of waste that can encourage the launch of a program movement on zero waste, so that the community, especially the Menceh village, lacks understanding and knowledge to handle waste.
The success of the zero waste program cannot be separated from the awareness that people love their own environment and therefore, there is a need for media to encourage public awareness and gain knowledge about Waste Management with economic value, to create a zero waste culture.

The success of this program has an impact on the community, such as: loving the environment, always maintaining cleanliness, and being able to improve the economy by recycling the waste and so on [15]-[18]. Therefore, it is necessary to have an application that can be used as a medium of information to the community in order to provide an understanding of public awareness and knowledge about how to overcome waste problems in the digital or android-based form.

Android is a widely used portable operating system among the public users [19]. In today's era, many Android-based smartphone users are used as educational media to add insight and knowledge in various fields such as: education, social, economic, health and so on [20]-[24].

Android-based applications have also been developed or created by many researchers in various fields. Kurniastuti \& Kamil have created an application to see the nutritional status of infants according to the standards of the minister of health in Indonesia [25], an application used to select organic and inorganic waste for kindergarten students [26]. Furthermore, Saefi, Lukiati, \& Suarsini have created an android-based learning media for biology learning about cell structure and function [27]. Where their findings show that the application can be easy and useful for users, as well as increase their knowledge about the structure and function of cells in humans.

Furthermore, an Android-based English learning media application called English for Disability (EFORD) has been developed by Azmi, Maryono \& Yuana. Where this application is made so that blind students can understand the basics of English in grammar and speaking material [28]. Novaliendry, Darmi, 
Hendriyani, Nor, \& Azman has also created android-based applications as a media for digital simulation learning at the vocational education level [29].

Based on the foregoing, several researchers have created and even developed android-based applications in various fields. Meanwhile, this article discusses the process of developing/creating an education application, so that users can add knowledge and insight on how to handle or process waste to be more useful, and a zero-waste culture can be implemented properly.

\section{METHODS}

The type of research is Research and Development (R\&D) using the ADDIE (Analysis, Design, Development, Implementation, and Evaluation) model [30][33]. This model is used to develop waste education applications as a means of information to users so that the zero-waste program can be implemented.

The ADDIE model has five stages, namely: Analysis, Design, Development, Implementation, and Evaluation [34], [35] (see Figure 1). At the analysis stage, identification of the needed in designing this application, and ways to deliver a zero-waste program are carried out, as well as to make it easier to provide material regarding Waste Management.

Furthermore, at the design stage, a framework (interface design) is made for this application, which consists of several menu forms, namely: intro page, main menu, waste regulation, waste material, waste processing menu, and waste processing video.

At the development stage, the collection of materials regarding waste and the software used to develop this application is implemented [36][37]. Furthermore, product (application) validation is carried out by media experts and content experts regarding the applications that have been made.

At the implementation stage, the activities carried out apply the product that has been developed in the form of an Android-based waste education media. This stage is performed starting from providing guidance to users on how to use this application of Zero Waste.

Then the last stage is evaluation. Where this stage is carried out on an evaluation of the application that has been made, by providing a questionnaire to the user, so that improvements are made to the media and additions if needed.

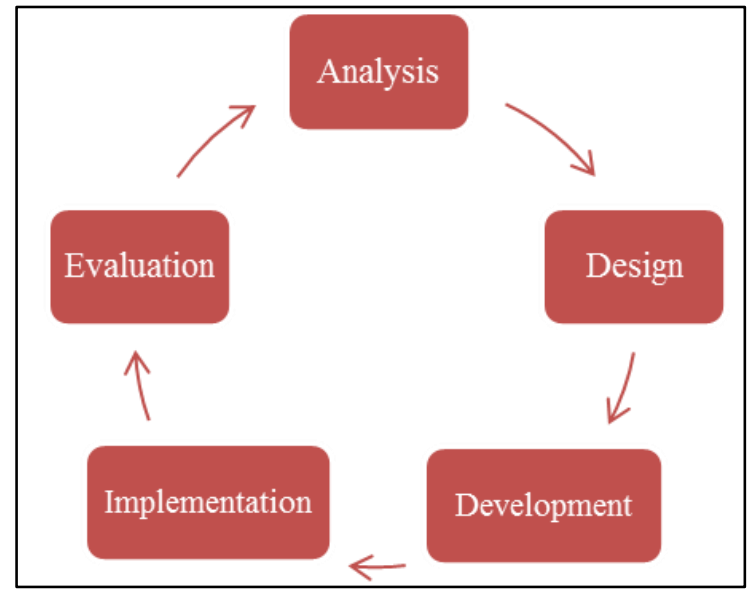

Figure 1. ADDIE Model

Subjects in this study amounted to 60 people. The data collection used is a questionnaire with a Likert scale (five options). Questionnaires are a number of written questions that are used to obtain information from respondents in terms of reports about themselves or other things that they know. For more details, the assessment on this scale can be seen in table 1

Table 1. Likert Score

\begin{tabular}{cc}
\hline Scale & Score \\
\hline Strongly Agree & 5 \\
Agree & 4 \\
Doubtful & 3 \\
Disagree & 2 \\
Strongly disagree & 1 \\
\hline
\end{tabular}

Meanwhile, the data analysis technique used in this study is descriptive statistical, namely by analysing quantitative data obtained from the results of filling out questionnaires by material experts, media experts and users to measure the feasibility and response of the applications that have been made. The data 
obtained from material (content) experts, media (design) experts, and user response are then summed and compared and then converted into percentages with the formula in equation 1 .

$$
\text { Value }(\%)=\frac{\text { total score }}{\text { ideal score }} \times 100 \%
$$

Furthermore, the results of the percentage of eligibility are then converted into the category of achievement of feasible, which can be seen in table 2. Furthermore, to find out the results of the user's response category can be seen in the Table 3.

\begin{tabular}{|c|c|c|}
\hline No. & $\begin{array}{l}\text { Achievement } \\
\text { percentage }(\%)\end{array}$ & Feasible Category \\
\hline 1 & $81-100$ & Very Feasible \\
\hline 2 & $61-80$ & Feasible \\
\hline 3 & $41-60$ & Enough Feasible \\
\hline 4 & $21-40$ & Less Feasible \\
\hline 5 & $0-20$ & Not Feasible \\
\hline
\end{tabular}

Table 3. Percentage of User Response Categories

\begin{tabular}{cc}
\hline $\begin{array}{c}\text { Achievement Percentage } \\
(\%)\end{array}$ & Interpretation \\
\hline $0-20$ & Very low \\
$20-40$ & Low \\
$40-60$ & Enough \\
$60-80$ & High \\
$80-100$ & Very high \\
\hline
\end{tabular}

\section{RESULT AND DISCUSSION}

\section{A. Result}

The results of the analysis according to the ADDIE model used are applications made using several supporting programs, namely Android Studio as the main software for programming applications and Adobe Photoshop as a supporting application for designing images in applications. Furthermore, the collection of materials and contents from this application: information about waste and Waste Management, the impact of waste, how to deal with waste and so on. Meanwhile, the hardware required to run or operate this application is an Android-based smartphone with a minimum version of Kit Kat 4.4.

In addition to collecting materials used to create applications, it is also important to obtain information regarding the management of waste that is used as the content of the application. This is in the form of information on regulations related to trash, sources and classification of waste, diseases caused by waste, and impacts on health.

The product (application) that we have created is an Android-based waste education media application consisting of several forms (menus) such as: intro page, main page, waste regulation menu, Waste Management menu, and waste materials.

The intro page is the interface that first appears when opening educational media. On this page, there is an animated text "MEDIA EDUKASI ZERO WASTE" which enlarges and then enters the main menu page. The intro page that can be seen can be seen in the Figure 1 .

Furthermore, on the main menu page, there are material menus namely REPAH (waste regulation), MAPAH (waste material), OPAH (waste processing) and there is an exit button on the top left to exit this application, which can be seen in Figure 2.

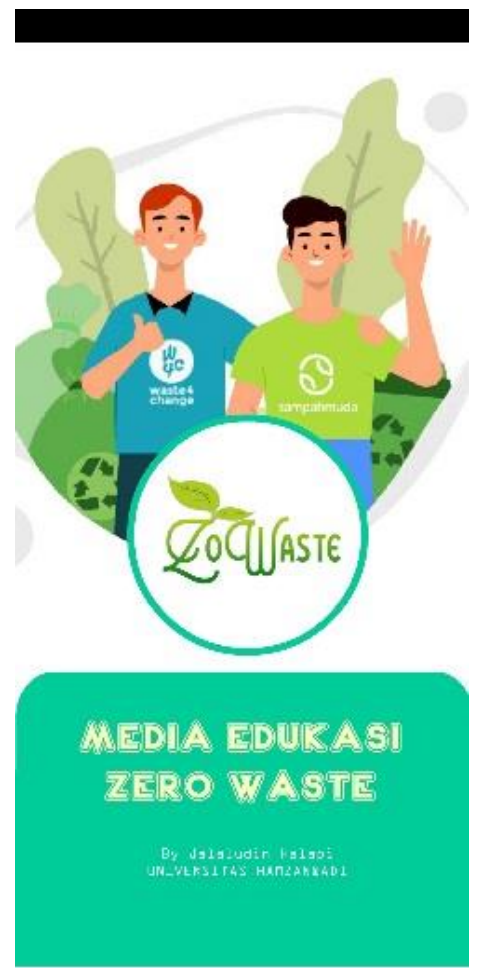

Figure. 1 Interface Intro 


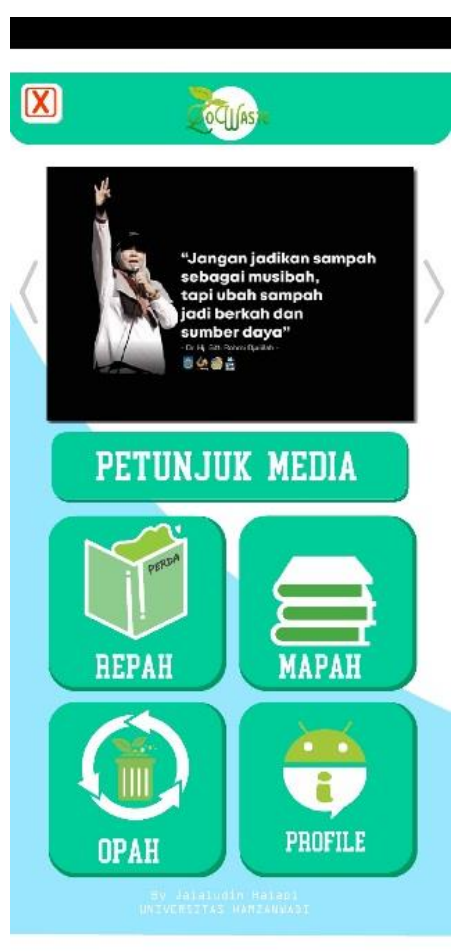

Figure 2. Interface Main Menu

The REPAH (Waste Regulation) menu is an application's display that has six menus which when pressed will enter the contents of the menu, namely regulations related to the rules governing trash and the back button which will direct to the previous menu. The display of this application can be seen in Figure3.

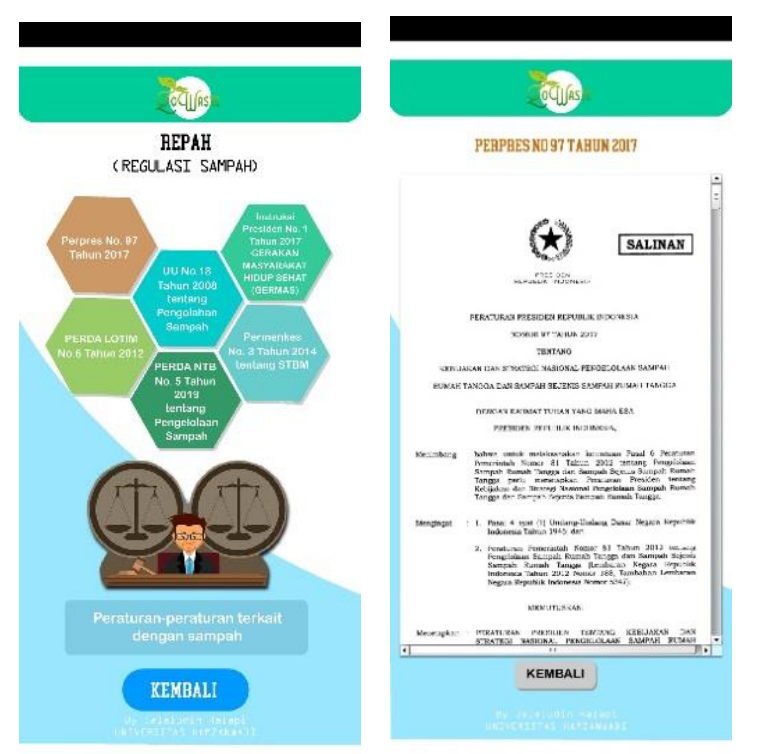

Figure. 3. Interface REPAH Menu (Waste Regulation)
MAPAH (Waste Material/Content) menu is a display where there are five menu options which when pressed will enter materials about Waste Management. The content of the material is in the form of images, text and animations, and there is a back button that will lead to the previous menu (see Figure4).

Furthermore, this menu (Figure4) also contains material that can provide education to users regarding the source and classification of waste, categorization waste, the impact of the presence of waste on human health and other living things, as well as diseases caused by the waste.

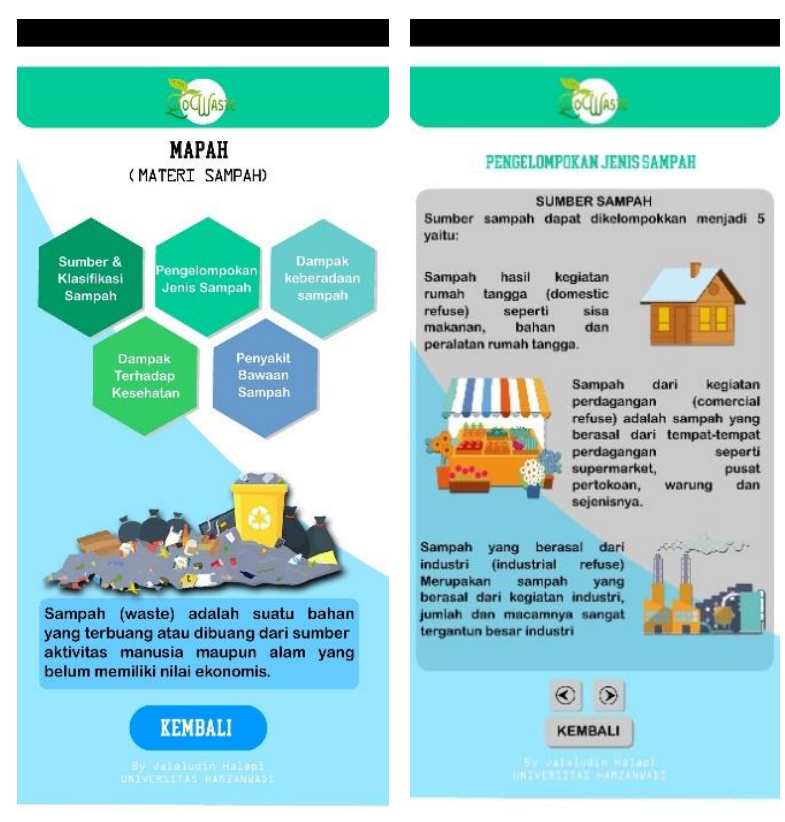

Figure 4. Interface of MAPAH menu (Material/Waste Content)

Next, the last one is to produce an OPAH (Waste Processing) Menu. This menu (form) is a page that has four menus which when pressed will enter the contents of materials on organic and inorganic waste processing, waste processing principles, waste processing methods, and waste processing videos.

This menu (Figure 5) contains material that can educate the public or users such as: how to process plastic waste, the methods used to process it, principles, and is presented in the form of an attractive video that is accompanied by animation. With this video, it can make it 
easier for users to understand how to process the waste. The display results from this menu can be seen in Figure 5.

After the product (application) has been developed, the next step is to test the feasibility of the product. In this activity, a media (design), material (content) test was carried out, and a usability test for 60 users.

The feasibility test for the interface design for this application consists of: appearance, programming, and benefits. The results we get are the display aspect has a percentage value of $79 \%$, while the value in the aspect is $85 \%$. Meanwhile, the value obtained in the benefits aspect is $85 \%$. for more details, our findings can be seen in table 4 and Figure 6 .

Table 4. Design Expert (Media) Feasibility Test Results

\begin{tabular}{llcc}
\hline No & \multicolumn{1}{c}{ Aspect } & Percentage & Category \\
\hline 1 & Display & $79 \%$ & Feasible \\
2 & Programming & $85 \%$ & Very Feasible \\
3 & Benefits & $85 \%$ & Very Feasible \\
\multicolumn{2}{c}{ Average percentage } & $83 \%$ & Very Feasible \\
\hline
\end{tabular}

Table 5. Material Expert (Content) Feasibility Test Results

\begin{tabular}{llcl}
\hline No & Aspect & Percentage & Category \\
\hline 1 & Content & $80 \%$ & Very Feasible \\
2 & Material & $83 \%$ & Very Feasible \\
& Presentation & & \\
3 & Language & $93 \%$ & Very Feasible \\
4 & Usefulness & $83 \%$ & Very Feasible \\
\multicolumn{2}{l}{ Average percentage } & $85 \%$ & Very Feasible \\
\hline
\end{tabular}

After conducting a feasibility test on the interface design, the next step is to test the feasibility of the material/content in the application. This test consists of four aspects, namely: content, presentation material, language, and usefulness. Based on Figure 7, the results obtained in the material aspect are $80 \%$, the material presentation aspect is $83 \%$, while the language aspect is $93 \%$, meanwhile, the benefits aspect is $83 \%$. So that the average results of the three aspects get a value of $85 \%$, and it can be concluded that this application belongs to the very feasible category.

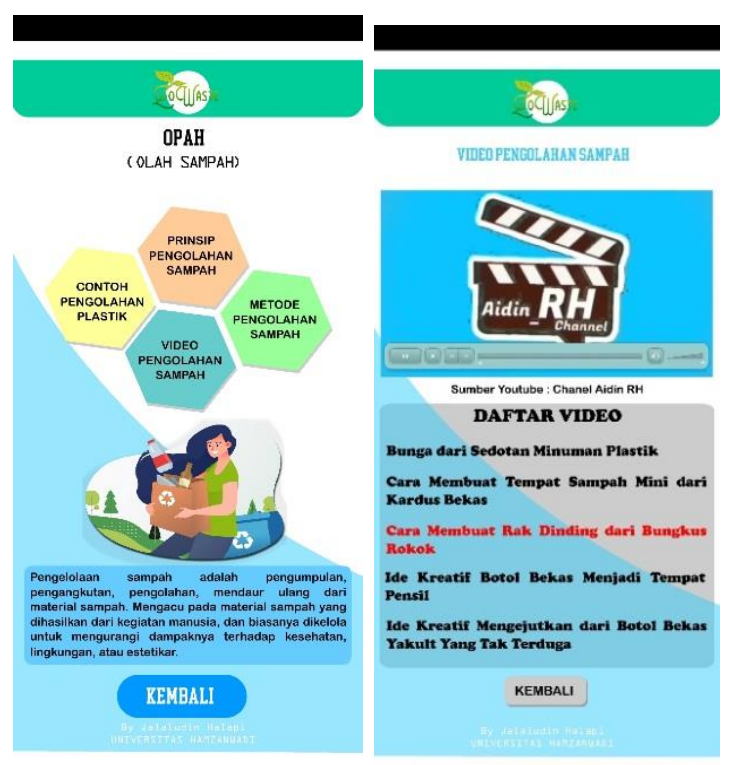

Figure 5. Interface of OPAH Menu (Waste Processing)

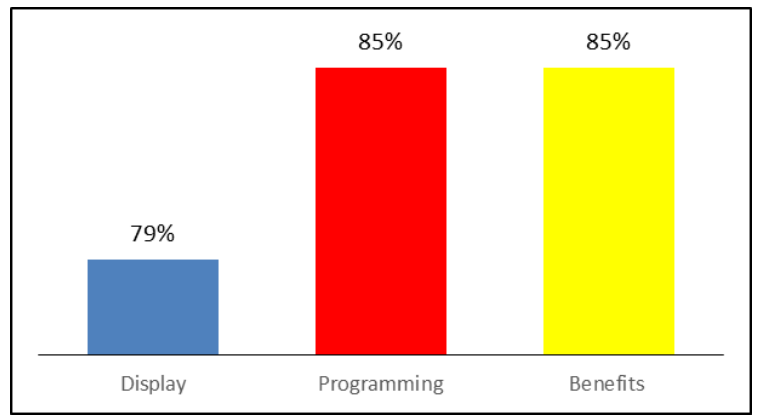

Figure 6. Diagram of Interface Design Feasibility Test

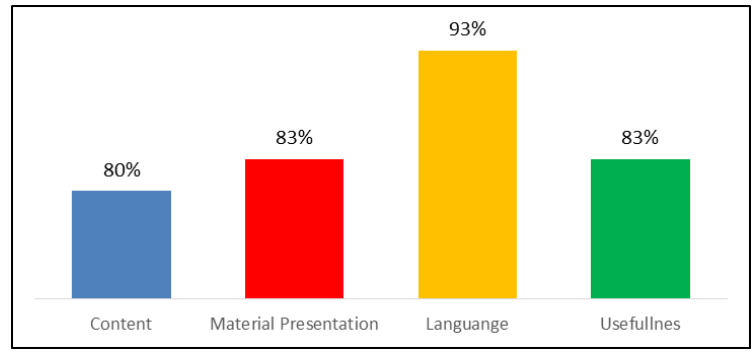

Figure 7. Diagram of Content/Material Feasibility Test

Furthermore, in this study usability test was conducted, which aims to determine the level of user response to the application that has been made. Our findings in table 6 and Figure 8 show that the usefulness-aspect gets a score of $84 \%$, while the easy of use aspects is $83 \%$, while the satisfaction aspect gets a score of $81 \%$. Based on these results obtained an average value of $83 \%$, so that the application (media) is in the very high category. 
Table 6. The Result of User Response

\begin{tabular}{llll}
\hline Usefullnes & $\begin{array}{l}\text { Ease } \\
\text { of Use }\end{array}$ & Satisfaction & Average \\
\hline $84 \%$ & $83 \%$ & $81 \%$ & $83 \%$ \\
\hline
\end{tabular}

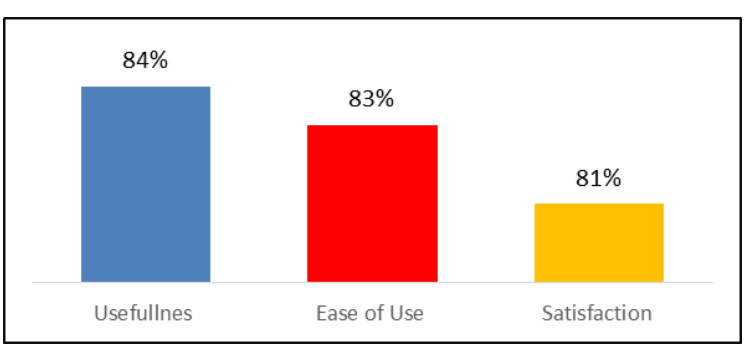

Figure 8. Diagram of Usability Testing Result

\section{B. Discussion}

Making this application is done with the ADDIE model through five steps, that is: analysis, design, development, implementation and evaluation. This application consists of four main menus, namely REPAH (waste regulation) which contains six laws relating to waste, MAPAH (waste material) which contains definitions, sources of waste and waste classification, impacts of waste and diseases caused by waste, OPAH (waste processing) which contains related methods of waste processing, principles of waste processing, and video tutorials on Waste Management. The material contained in this media is in the form of text, images and videos. To enter the material, then move, return and exit using the buttons provided.

The results of the overall material/content feasibility test obtained a percentage of an average of $85 \%$ (in table 5) in the very feasible category. Based on these results indicate that the application has material / content that is in accordance with the objectives and can help users achieve the goals of this application. In addition, the material in this application is easy to understand, presented quite complete, systematic, attractively packaged, and the pictures in it are very clear.

Based on this, our findings are relevant to [25]-[27], [38], [39], where their findings are that the products that have been developed are very feasible and meet the standards of the content.

Meanwhile, in terms of language, this application is in accordance with the rules of good and correct language, communicative, and in accordance with the target media. Furthermore, in terms of users, this application can improve users' understanding of the material so that it attracts users' attention and increases user knowledge and insight.

The results of the overall feasibility test by media/design experts (in table 4) obtained a percentage of an average of $83 \%$ in the very feasible category. From these results, this application has a standard text format, use of colour, image quality, animation/simulation, layout of text, animation, and images, as well as good user-interactivity and ease of use.

In addition, this application can increase user attention in using it, and is easy to operate. Our findings are relevant to [25], [27], where their findings are that the products/applications that have been made are in accordance with usage standards, in terms of appearance, images, and some of the functions of the buttons on the application.

Furthermore, the last is the result of the user's response/usability test for this application is to obtain an average value of $83 \%$ and is classified as very high ( $\mathrm{VH}$ ) (in table 6). Based on these results indicate that the use of this application has a VH response from users, this is because this application is needed and will be useful to the community (users), and can help as their information media. In addition, it makes it easier for users to learn about waste.

The results of the applications that have been made have been able to run as expected, simple and practical to use, also do not require complicated steps to operate. In addition, this can operate easily without the need for instructions and is facile to remember. Also, this application is very good, convenient to use, and users feel happy

This application can also be used on other devices (smartphones), as long as the 
device used the Android operating system. other than that, this application is practical to use because there is no difficulty in using it. Our findings are relevant to [21], [28], [40]-[43]. Their findings are that users feel satisfied and happy, and are comfortable with this application, so they always feel like using it to solve the waste problem in today's era.

\section{CONCLUSION}

Based on our findings, it can be concluded that this application is very feasible to use in terms of content regarding waste with a percentage of $85 \%$. Furthermore, in terms of the appearance/design of the application that we have created, we get a score of $83 \%$ (very feasible), and users have a very high response category from the usability aspect (83\%), so that users feel that this application is easy to understand, easy to use, useful, and they gain knowledge about how to deal with waste in their environment. In addition, with this application, the zero waste program that has been set by the government can be carried out as it should.

The suggestion from our findings is that this application needs to be developed again so that it can be accessed online, because this is only in the offline form. In addition, this application can be further developed in the future so that user interest is even higher, so that awareness the people pay attention to the problem of waste, its prevention, impact, and diseases caused by the waste.

\section{REFERENCES}

[1] I. N. Wardi, "Pengelolaan sampah berbasis sosial budaya: Upaya mengatasi masalah lingkungan di Bali," Bumi Lestari J. Environ., vol. 11, no. 1, pp. 167-177, 2011.

[2] K. Kabirifar, M. Mojtahedi, C. Wang, and V. W. Y. Tam, "Construction and demolition waste management contributing factors coupled with reduce, reuse, and recycle strategies for effective waste management: A review," J. Clean. Prod., vol. 263, pp. 1-16, 2020 ,

doi: https://doi.org/10.1016/j.jclepro.2020.121265
[3] J. van Heek, K. Arning, and M. Ziefle, "Reduce, reuse, recycle: Acceptance of CO2utilization for plastic products," Energy Policy, vol. 105, pp. 53-66, 2017.

[4] S. Weber, J. Lynes, and S. B. Young, "Fashion interest as a driver for consumer textile waste management: reuse, recycle or disposal," Int. J. Consum. Stud., vol. 41, no. 2, pp. 207-215, 2017.

[5] M. Zulkifli, A. F. Ayub, and M. Shery, Statistik Sumber Daya Laut dan Pesisir Sampah Laut Indonesia. Jakarta: Badan Pusat Statistik/BPS-Statistics Indonesia, 2019.

[6] E. Fagnani and J. R. Guimarães, "Waste management plan for higher education institutions in developing countries: The Continuous Improvement Cycle model," J. Clean. Prod., vol. 147, pp. 108-118, 2017.

[7] NTB, "Peraturan Gubernur Nusa Tenggara Barat Nomor 44 Tahun 2019 Tentang Program Strategis dan Unggulan Daerah dalam Pencapaian Indikator Kinerja Utama Pemerintah Provinsi Nusa Tenggara Barat Tahun 2019-2023.” Mataram, 2019.

[8] I. W. Widiarti, "Pengelolaan Sampah Berbasis 'Zero Waste' Skala Rumah Tangga Secara Mandiri," J. Sains \&Teknologi Lingkung., vol. 4, no. 2, pp. 107-145, 2012, doi: 10.20885/jstl.vol4.iss2.art4.

[9] F. Compagno, "Recycling 2020-Reduce, Reuse, and Recycle: The case TerracinaFilomena Compagno-Terracina Zero Waste activist, Italy," J. Nucl. Energy Power Gener. Technol., vol. 4, no. 1, pp. 1-2, 2020.

[10] S. Singh, S. Ramakrishna, and M. K. Gupta, "Towards zero waste manufacturing: A multidisciplinary review," J. Clean. Prod., vol. 168, pp. 1230-1243, 2017.

[11] S. Hamid, B. M. Skinder, and M. A. Bhat, "Zero Waste: A Sustainable Approach for Waste Management," in Innovative Waste Management Technologies for Sustainable Development, IGI Global, 2020, pp. 134-155.

[12] N. Pietzsch, J. L. D. Ribeiro, and J. F. de Medeiros, "Benefits, challenges and critical factors of success for Zero Waste: A systematic literature review," Waste Manag., vol. 67, no. 1, pp. 1-29, 2017, doi: 10.1016/j.wasman.2017.05.004.

[13] A. Mesjasz-Lech, "Reverse logistics of municipal solid waste-towards zero waste cities," Transp. Res. Procedia, vol. 39, pp. 320-332, 2019.

[14] K. S. Vignesh, S. Rajadesingu, and K. D. Arunachalam, "Challenges, issues, and 
problems with zero-waste tools," in Concepts of Advanced Zero Waste Tools, Elsevier, 2021, pp. 69-90.

[15] A. E. Adeniran, A. T. Nubi, and A. O. Adelopo, "Solid waste generation and characterization in the University of Lagos for a sustainable waste management," Waste Manag., vol. 67, pp. 3-10, 2017.

[16] C. Khaw-ngern, "Zero Waste Management through Mindful Consumption for Sustainable Waste Solution," Psychol. Educ. J., vol. 58, no. 1, pp. 1387-1392, 2021.

[17] H. Saleh, B. Surya, and H. Hamsina, "Implementation of sustainable development goals to Makassar zero waste and energy source," Int. J. Energy Econ. Policy, vol. 10, no. 4, pp. 530-538, 2020.

[18] K. Willis, C. Maureaud, C. Wilcox, and B. D. Hardesty, "How successful are waste abatement campaigns and government policies at reducing plastic waste into the marine environment?," Mar. Policy, vol. 96, pp. 243-249, 2018.

[19] V. R. Niveditha and T. V Ananthan, "Improving Acknowledgement in Android Application," J. Comput. Theor. Nanosci., vol. 16, no. 5-6, pp. 2104-2107, 2019.

[20] S. Wahyuni, "Studentsâ€ $€^{\mathrm{TM}}$ Perception of Using an Android Smartphone Application as a Supplementary Learning Resource," Asia Proc. Soc. Sci., vol. 2, no. 4, pp. 115-119, 2018.

[21] J. Alawode and J. Adegboye, "Usability Analysis for An Android Based Application," J. Women Tech. Educ. Employ., vol. 1, no. 1, pp. 84-89, 2020.

[22] C. B. Haas, A. Scrol, C. Jujjavarapu, G. P. Jarvik, and N. B. Henrikson, "Usefulness of mobile apps for communication of genetic test results to at-risk family members in a US integrated health system: A qualitative approach from user-testing," Heal. Policy Technol., vol. 10, no. 2, p. 100511, 2021.

[23] S. Mukhtar and K. Putri, "Technology Integrated on Media Literacy in Economic Studies on Higher Education," J. Soc. Stud. Educ. Res., vol. 12, no. 1, pp. 95-123, 2021.

[24] H. Du et al., "Development and feasibility testing of an interactive avatar education application for education of patients with heart failure," Br. J. Card. Nurs., vol. 15, no. 6, pp. $1-13,2020$.

[25] I. Kurniastuti and A. S. Kamil, "Rancang Bangun Aplikasi Status Gizi Bayi Berbasis Android," Elinvo (Electronics, Informatics, Vocat. Educ., vol. 4, no. 1, pp. 24-29, 2019.
[26] H. Rahmayanti, V. Oktaviani, and Y. Syani, "Development of sorting waste game android based for early childhood in environmental education," in Journal of Physics: Conference Series, 2020, vol. 1434, no. 1, p. 12029.

[27] M. Saefi, B. Lukiati, and E. Suarsini, "Developing Android-Based Mobile Learning On Cell Structure And Functions Lesson Subject Topic To Optimize Grade XI Students' Cognitive Comprehension," J. Pendidik. Sains, vol. 5, no. 2, pp. 57-63, 2017.

[28] N. Azmi, D. Maryono, and R. Yuana, "Development of an Android-based Learning Media Application for Visually Impaired Students," Indones. J. Informatics Educ., vol. 1, no. 1, pp. 61-68, 2017.

[29] D. Novaliendry, R. Darmi, Y. Hendriyani, M. Nor, and A. Azman, "Smart Learning Media Based on Android Technology," Int. J. Innov. Creat. Chang., vol. 12, no. 11, pp. 715-735, 2020.

[30] T. Trust and E. Pektas, "Using the ADDIE model and universal design for learning principles to develop an open online course for teacher professional development," J. Digit. Learn. Teach. Educ., vol. 34, no. 4, pp. 219233, 2018.

[31] R.-A. Salas-Rueda, É.-P. Salas-Rueda, and R.D. Salas-Rueda, "Analysis and design of the web game on descriptive statistics through the ADDIE model, data science and machine learning," Int. J. Educ. Math. Sci. Technol., vol. 8, no. 3, pp. 245-260, 2020.

[32] M. E. Ismail, P. Utami, I. M. Ismail, N. Hamzah, and H. Harun, "Development of massive open online course (MOOC) based on addie model for catering courses," J. Pendidik. Vokasi, vol. 8, no. 2, pp. 184-192, 2018.

[33] A. Bamrara and P. Chauhan, "Applying ADDIE model to evaluate faculty development programs," Int. J. Smart Educ. Urban Soc., vol. 9, no. 2, pp. 25-38, 2018.

[34] M. K. Hakky, R. H. Wirasasmita, and M. Z. Uska, "Pengembangan media pembelajaran berbasis android untuk siswa kelas x pada mata pelajaran sistem operasi," EDUMATIC J. Pendidik. Inform., vol. 2, no. 1, pp. 24-33, 2018.

[35] N. Aini, R. H. Wirasasmita, and M. Z. Uska, "Pengembangan Mobile Learning Berbasis Android Pada Mata Pelajaran Jaringan Dasar," EDUMATIC J. Pendidik. Inform., vol. 2, no. 1, pp. 34-41, 2018.

[36] B. D. D. Arianti, “Aplikasi Simulasi Tes Toefl Berbasis Android di Fakultas Keguruan dan Ilmu Pendidikan Universitas Hamzanwadi," Edumatic J. Pendidik. Inform., vol. 3, no. 1, 
pp. 30-36, 2019.

[37] U. Irawan and R. H. Wirasasmita, "Media Pembelajaran Video Tutorial Interaktif Berbasis Adobe Flash Pada Mata Kuliah Pemrograman Dasar," Edumatic J. Pendidik. Inform., vol. 3, no. 2, pp. 84-90, 2019.

[38] H. Prabowo and F. Arifin, "Pengembangan Media Pembelajaran Kendali Fuzzy Logic Berbasis Arduino Nano Pada Mata Kuliah Praktik Sistem Kendali Cerdas," Elinvo (Electronics, Informatics, Vocat. Educ., vol. 3, no. 1, pp. 39-45, 2018.

[39] U. Cahyana, M. Paristiowati, and S. Fauziyah, "Development of Android-Based Mobile learning media on Atomic Structure and Periodic Table," in IOP Conference Series: Materials Science and Engineering, 2018, vol. 434, no. 1, p. 12095.

[40] S. A. Wicaksono, D. R. Firdausy, and M. C. Saputra, "Usability testing on android application of infrastructure and facility reporting management information system," $J$. Inf. Technol. Comput. Sci., vol. 3, no. 2, pp. 184-193, 2018.

[41] S. M. S. Al-Gayar, "Testing the Usability of the MediCare System," Turkish J. Comput. Math. Educ., vol. 12, no. 3, pp. 3227-3237, 2021.

[42] R. Raymond, R. Suhatman, and M. Dewi, "Pembangunan Game Memory Training terhadap Peningkatan Short Term Memory (STM) pada Anak SMP Menggunakan Speech Recognition (Studi Kasus: SMP Dharma Loka Pekanbaru)," J. Nas. Teknol. dan Sist. Inf., vol. 4, no. 2, pp. 61-72, 2018, doi: 10.25077/teknosi.v4i2.2018.61-72.

[43] R. K. Dewi, N. D. Priandani, K. C. Brata, and L. Fanani, "Usability evaluation of mobilebased application for Javanese script learning media," J. Inf. Technol. Comput. Sci., vol. 3, no. 1, pp. 88-93, 2018. 